\title{
Medieval Utraquist Sermons on Czech Patron Saints
}

Jindřich Marek

(Charles University, Prague)

\begin{abstract}
This article analyses medieval sermons about Czech patron saints given by Czech Utraquists using digital humanities tools. Lists of sermons by Jan Hus and Czech Utraquists about Czech patron saints are provided in the appendices.
\end{abstract}

\section{Keywords}

sermon; Czech Utraquists; Czech patron saints; quantitative analysis; Middle Ages 
Preaching was an important part of literary culture in late mediaeval Bohemia, but research has paid only limited attention to the sermons delivered by both Czech Catholics and Utraquists. ${ }^{1}$ Preaching, despite its significant representation in preserved manuscripts, is a specific genre on the periphery of the literary field. It primarily originated in pastoral work and differed from the "high" genres of literature. The first suitable step would thus be to perform a quantitative analysis of the preserved sermons.

Postils are collections of sermons for Sundays and feasts during the Liturgical Year. Some include texts for the feasts of saints, either collections for the whole year or special, artificial collections dedicated to individual saints. Sermons on the saints are specific because the selection of the saints in a particular collection represent the editor's preferences. They also provide evidence of development in the cults of individual saints. In Western Europe, preachers' interest in saints grew from the $13^{\text {th }}$ century. The research thus far has focused on this period and resulted in a typology of sermons about saints. ${ }^{2}$

Czech Utraquists also preached on the feast day of saints. The contemporary criticism made by Catholics who claimed Utraquists did not recognise the feasts of saints has thus been proven to be unjustified, though heretofore research only marginally dealt with preserved Utraquist sermons. ${ }^{3}$ While noting the preaching, it has focused on the work of individual preachers, on anonymous collections, ${ }^{4}$ or in rare cases it addressed the individual saints. ${ }^{5}$ However, a thorough investigation and overall evaluation of Utraquist sermons on saints, both of the texts and the material features of the records is still lacking.

It must be noted that the initial situation is favourable for research. The corpus of Utraquist postils is clearly defined, at least at the level of whole collections. ${ }^{6}$ In addition, it is easy to distinguish three generations of Utraquist preachers and to compare their work with the preaching of Jan Hus. ${ }^{7}$ In this article, I would like to analyse medieval Utraquist sermons on Czech patron saints (up to 1526, which is the traditional end-point of the Middle Ages in Bohemia), as these sermons testify not only to the religious, but also the national identity of their authors. ${ }^{8}$ In the appendix, I included complete lists

1 Rejchrtová (1991); Uhlír (2005); Klaniczay (2018).

2 Ferzoco (1996); Ferzoco (2002).

3 Halama (2002); Halama (2006); Horníčková (2018).

4 Marek (2005); Marek (2011); Halama (2016).

5 Molnár (1963); Kadlec (1968); Uhlîr (1996); Kadlec (1997); Vidmanová (1997); Rejchrtová (1997); Marek (2016).

$6 \quad$ Spunar (1978); Spunar (1985); Spunar (1995).

7 I consider Jakoubek of Stř́bro, Jan of Př́bram, and Prokop of Plzeň as members of the first generation of Czech Utraquists, Jan Rokycana, Martin Lupáč, Václav of Dráchov, and Jakub of Jemnice as members of the second generation and Wenzel, parish priest at St Gallus and Michal Polák as members of the third generation. For practical reasons, anonymous sermons of each generation are represented as one pseudoauthor.

8 I use the traditional list of Czech patron saints venerated in Bohemia in the Middle Ages including St Vitus and St Sigismund who did not live in Bohemia. Cf. Beran (1931). Unlike sermons, the context of liturgy is not researched here, as it would require an extensive specialized study. It would be also desirable to extend the future research until 1620. 
of Jan Hus's preserved sermons about Czech patron saints as well as those by Utraquist preachers. $^{9}$

As illustrated in Appendix 1, Jan Hus is the author of 33 sermons in four collections on Czech patron saints and Utraquist preachers wrote 124 sermons in 26 collections over a century. ${ }^{10}$ The most prolific Utraquist author was Jakoubek of Stř́ibro with 22 preserved sermons. Jan Rokycana and Václav of Dráchov are the authors of 13 texts each, Jan of Příbram is credited with 12 texts, and other authors each wrote less than 10 sermons. $^{11}$

There are only five Czech-language sermons in the whole body of work, all coming from second-generation Utraquist authors. These are the sermon on Saint Vitus (preserved in eight records), the only one dedicated to a Czech patron saint included in the postil of Jan Rokycana; and anonymous sermons about Wenceslaus, Procopius, Vitus, and the Five Holy Brothers preserved in two different collections.

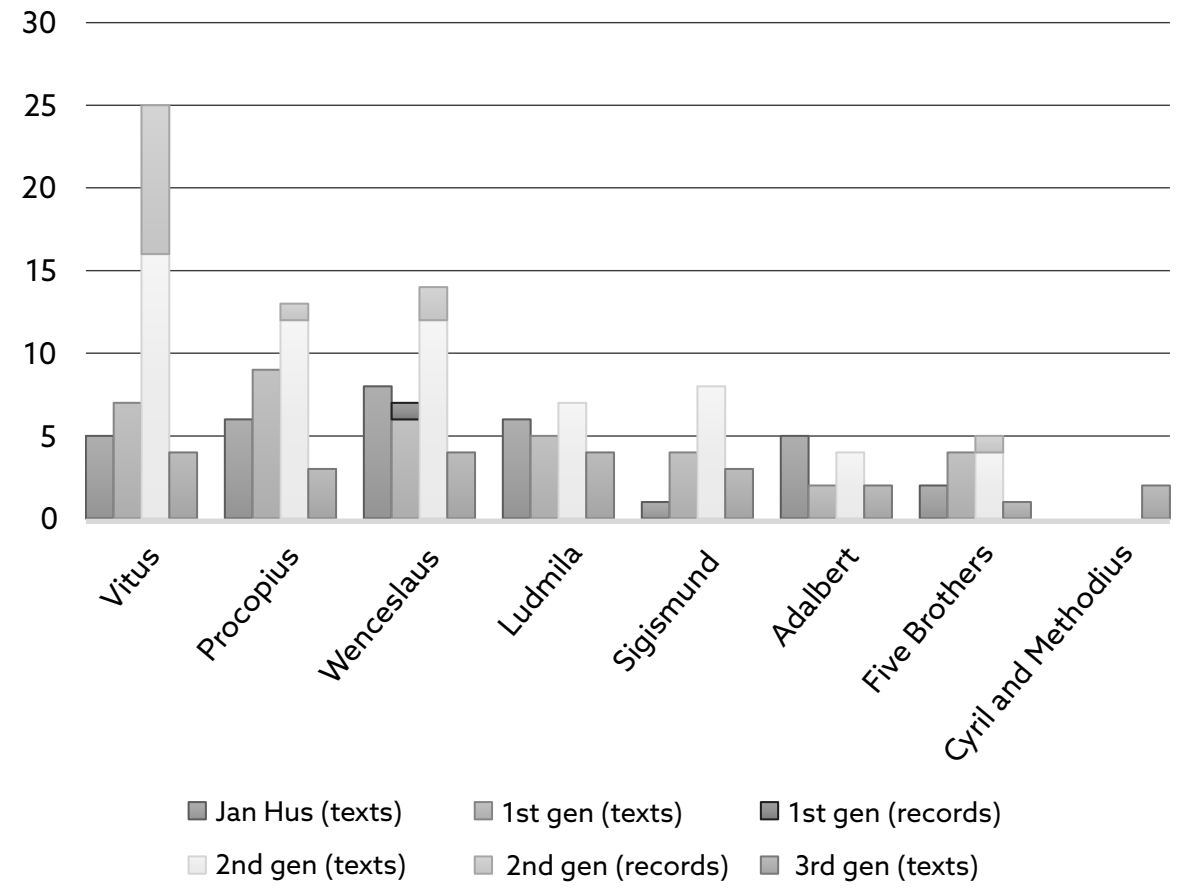

The number of sermons by Jan Hus and three generations of Czech Utraquists on individual Czech patron saints.

9 The entries include the number, the author of the sermon (or collection in the case of Jan Hus), the reference to the manuscript preservation or edition, and finally the pericope.

10 Three sermons are counted multiple times, for each generation that used them.

11 In addition, 2 radical collections with 10 and 11 sermons survived, but at least one of these collections has more sermon cycles. 
Chart 1 shows the number of feast sermons about individual Czech patron saints by Jan Hus and three generations of Czech Utraquists. The trio of Wenceslaus, Ludmila, and Procopius dominate among Hus's works, followed by Vitus and Adalbert. This changed for the later Utraquists, however. The main Czech patron saints for them were Vitus, Procopius, and Wenceslaus, followed by Ludmila and Sigismund, and then a greater gap to Adalbert, the Five Holy Brothers, and Cyril and Methodius. While the first generation favoured Procopius, the second preferred Vitus, who became the topic of an increasing number of both unique texts and transcripts. There are significantly more sermons authored by the second generation of the Czech Utraquists about the most favoured saints. The third generation only created a few texts, which shows a shifted situation concerning saints. The probable explanation is this new generation could use the rich production from the previous one, but it is important to note that printing had no effect because no sermon on a Czech patron saint was printed during the Middle Ages. Interest in individual saints (except for Cyril and Methodius) developed analogously: After the first generation, whose production is comparable to Jan Hus, the second generation produced a significant increase in output, while the third generation only marginally contributed to the corpus.

Besides the number of sermons, it is possible to quantify some of their features. The first is the pericope used in the sermon. There were no fixed pericopes for the feasts of the saints, so the choice of the pericope itself testifies to the intention of the sermon's author. The pericope was the starting point for interpreting either the theme or the exact biblical text depending on the genre (thematic sermon or exegetic homily).

For each sermon, I recorded three data points: the author, the saint, and the pericope. Each sermon is represented as a triangle of relations between the author, the saint, and the pericope. I visualised the resulting data in a network chart. This approach does not represent a social network analysis as three different classes of nodes are mixed in one chart. It was not possible to create a genuine network diagram as most network analysis methods are unusable because of the heterogeneity and auxiliary character of the pseudo-network constructed. However, all these nodes represent attributes of individual sermons and give context that can be interpreted by reading the graph. I consider the relation of the saint to the pericope as especially important.

It turns out that the preaching of Jan Hus, despite using a greater number of pericopes than the later Czech Utraquists, fits into the whole and there is no eccentricity in the network. With or without Hus, the strong connection between specific pericopes and saints, especially those most represented in the collections, is visible in the chart. Jakoubek of Stříbro, Jan of Příbram, Jan Rokycana, and Václav of Dráchov were significant Hussite authors of sermons about Czech patron saints whose work was at least comparable to one another.

The partial data presented in separate charts allows for a more detailed characterization of the individual generations of Czech Utraquists. In the first generation, Jan of Příbram interpreted excerpts from the Old Testament alongside New Testament pericopes. In the second generation, Václav of Dráchov, who was the most conservative of his generation, followed him in this respect. Preaching among the third generation was 


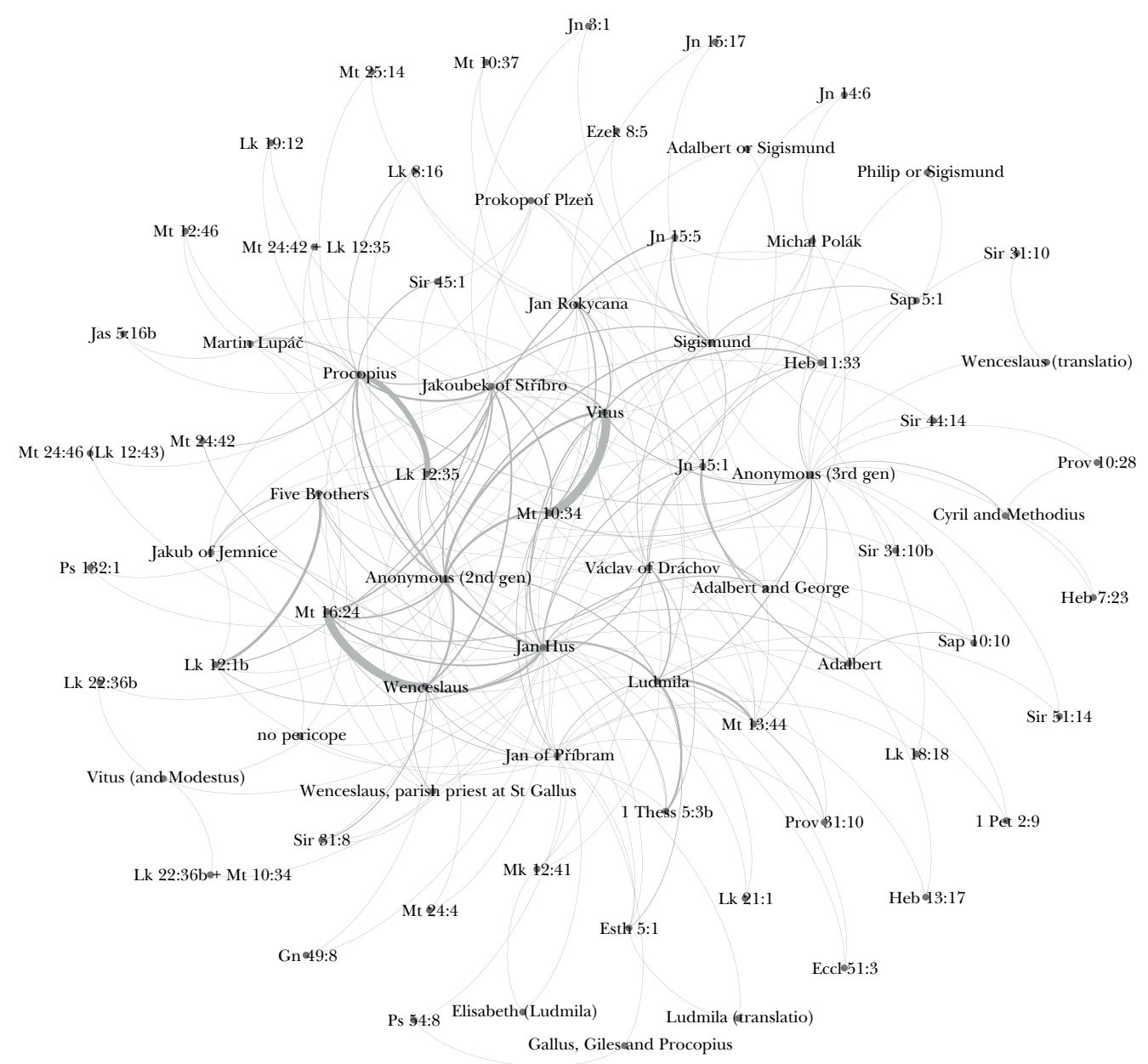

Sermons by Jan Hus and Czech Utraquists (network chart). Names of authors are connected with names of saints that are present in their sermons and both authors and saints are connected with pericopes used. The line width indicates the amount of sermons (the thicker, the more sermons).

complementary to that of both previous generations and more often interpreted excerpts from the Old Testament or Epistles. Many sermons have been preserved without knowledge of the author, which suggests that this generation did not create "authorauthorities" as the previous two had.

Based on the popularity of saints and the stability of the pericopes used, it is possible to define three classes of saints in the analysed material: a) the popular: Vitus, Procopius, Wenceslaus; b) the less popular: Ludmila, the Five Brothers; c) and the marginal: Sigismund, Adalbert, Cyril, and Methodius. A single predominantly used pericope contributed to the lasting picture of some saints, especially the most favoured, such as 


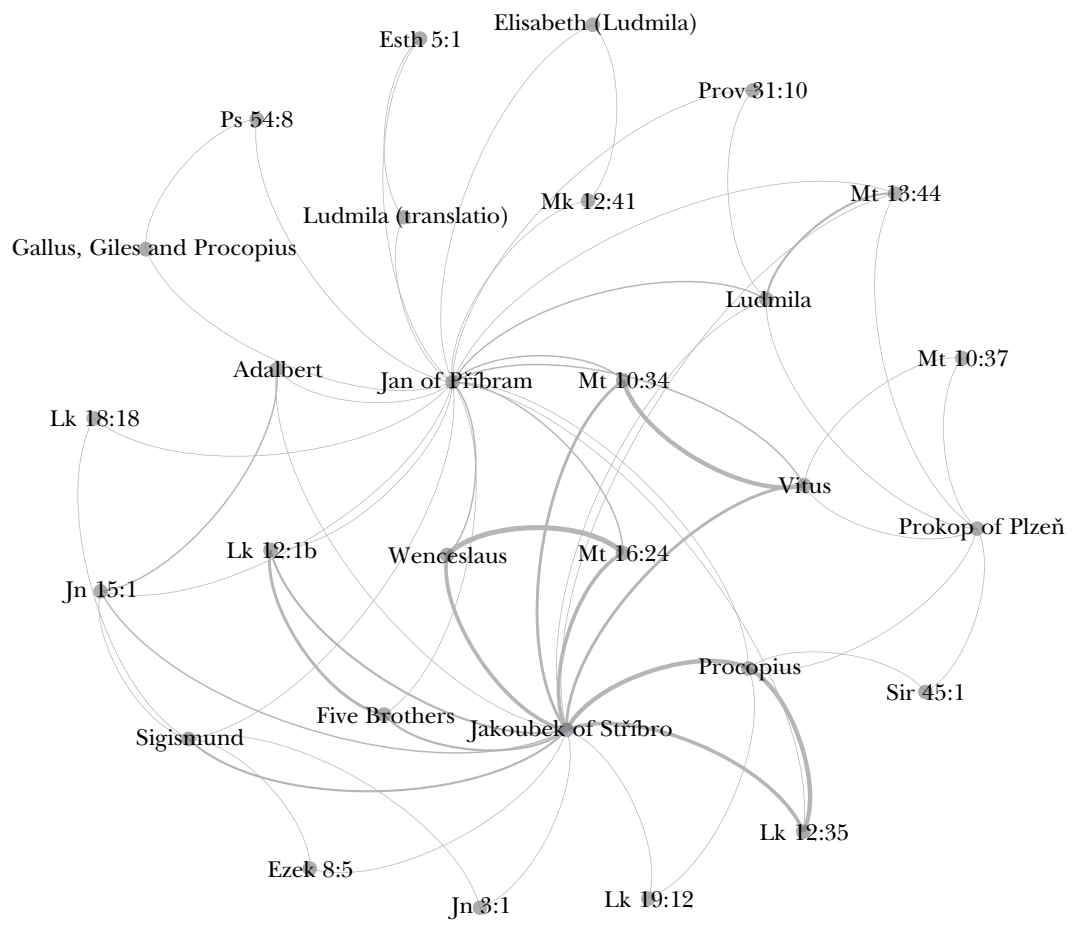

Sermons by the first generation of Czech Utraquists (network chart)

Wenceslaus. ${ }^{12}$ On the contrary, the pericope Ego sum vitis vera (Jn 15:1), which was used for preaching about a martyr (de uno martyre), was often used in the sermons about less popular Czech patron saints who were martyrs. ${ }^{13}$ A worthy testimony where Vitus, Procopius, and Wenceslaus were perceived as the foremost Czech patron saints is the sermon on Saint Wenceslaus by Jakoubek of Stříbro, where the author names the three most popular saints (including Vitus) as examples of saintly men from the Czech nation. ${ }^{14}$

The sermons presented all patron saints as archetypes and models for imitation: Vitus, Wenceslaus, and Adalbert as martyrs, and Procopius as a confessor. They are almost void of narrative elements; the only exceptions being the sermon about Ludmila and Jakoubek's sermon on Wenceslaus. In terms of genre, the texts are thematic sermons or exegetic homilies. Distinctions are present in the introduction and the text is divided

12 Marek (2016).

13 As evidenced by the rubrics of sermons, the feasts of the martyrs Adalbert and George, which follow each other in the calendar year, have often been associated. To a lesser extent, this was similar to other saints. The feast of Sigismund used the same pericope as the one of Adalbert and a replacement pericope, usually for one of the feasts close in the calendar, was used instead.

14 Et ergo populus Boemicus posset bene laudari et eciam vituperari. In hoc laudari, quod Deus excitavit multos sanctos homines sicud sanctum Venceslaum, Procopium, Vitum. Et eciam in multis sunt vituperandi sicut mali principes et malus clerus et alia multa mala, que permittunt in regno suo. Et illos sanctos, quos vivos voluerunt foveri, iam mortui existentes venerant et honorant etc. NK X G 11, fol. $155 \mathrm{v}$. 


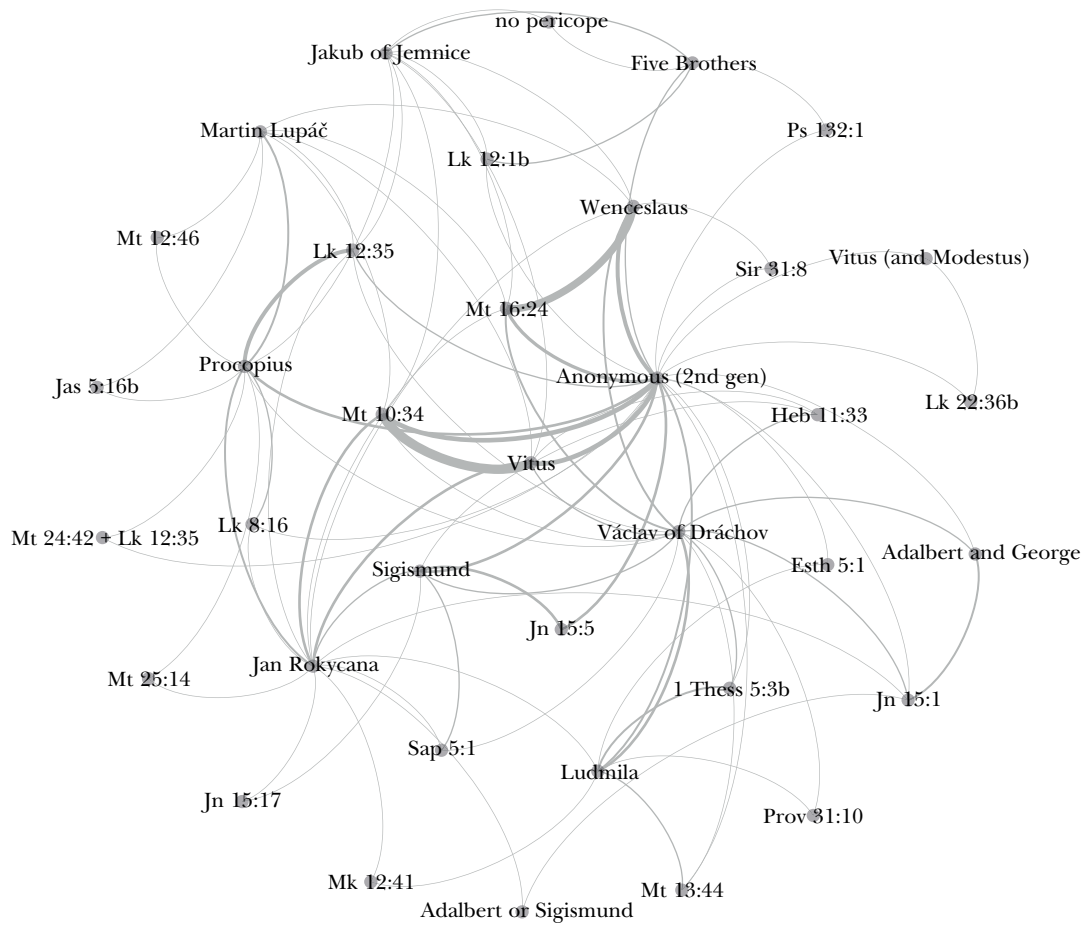

Sermons by the second generation of Czech Utraquists (network chart)

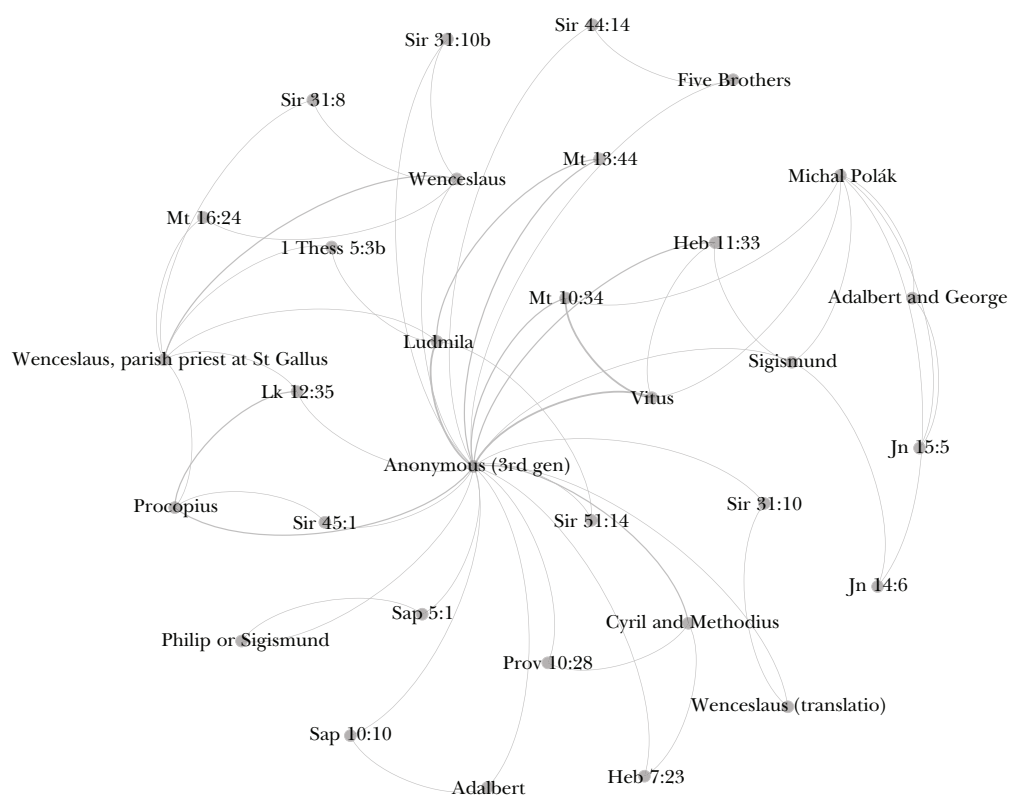

Sermons by the third generation of Czech Utraquists (network chart) 
into points, helping to abstract the theme. The exegetic homily is common, exposing the individual parts of the pericope.

Based on comparison of each text with others, the analysis also showed the reception of older texts from one sermon collection to another and from one author to another (including the reception between generations). It took different forms: reception of full texts or of the prothemata only. In many cases, the sermons were "fluid texts" whose structure changed over time. However, it was impossible to display the reformulation of older texts in charts because there were different degrees in individual cases, something that is difficult to quantify. In the terms of the reception of the text, Jakoubek of Stříbro had an influence on the preaching of Jan of Příbram and Jan Rokycana. The conservative Jan of Příbram had a similar influence on Václav of Dráchov, who, like Jan Rokycana, was a representative of the Hussite "moderate party" but in public affairs proved himself to be a more conservative element. The sermons of Jakub of Jemnice had their Czech-language adaptations and their influence was passed down from the second generation to the third. However, I will present these observations created during the registration and quantification of the material in a suitable form with detailed references to the sources later. I especially refer to the reception of complete older texts in later sermons in the annexes to this article.

Earlier scholars have claimed the cult of the patron saints was important, not only for Czech Catholics, ${ }^{15}$ but also for Utraquists. ${ }^{16}$ I based the presented research on a quantitative analysis using digital humanities tools. This method made a complete processing of these sermons possible for the first time, including a preliminary evaluation of the content. The research confirms the view that "the veneration of Czech patron saints by members of the Utraquist Church in Bohemia did not differ from the veneration these saints enjoyed in the Roman Church" ${ }^{17}$ In the future, it is desirable to not only extend the research to all Utraquist sermons on saints, but to also compare Utraquist and Catholic sermons. ${ }^{18}$

\section{Abbreviations}

Kapit Library of the Metropolitan Chapter at St Vitus (Prague)

KNM Library of the National Museum (Prague)

15 Kadlec (1968); Šmahel (1971); Kadlec (1997).

16 Halama (2002); Halama (2006); Halama (2016). The only unclear question was whether the Hussites venerated Cyril and Methodius: Kopecký (1965); Zlámal (1967); Šmahel (1971).

17 Halama (2006: p. 196).

18 The collections of Czech Catholics from the $15^{\text {th }}$ and the beginning of the $16^{\text {th }}$ century are difficult to date and differentiate from the transcriptions of standard compendia due to insufficient identification in catalogues. Catholic preaching, according to the current state of knowledge, "displays a substantially different picture" than the Utraquist one. Preaching among Catholic exiles differs from the preaching of Catholics who stayed in Bohemia: Older works were transcribed and disseminated, and conservatism and politicisation were clear in the emerging sermons. Uhliřr (1996: p. 37). 
NK National Library of the Czech Republic (Prague)

Strahov The Strahov Library (Prague)

\section{Bibliography}

\section{Primary Sources (Manuscripts)}

Jan Hus, Puncta. Manuscript, Národní knihovna ČR (Prague), IV F 25.

Jakoubek of Stř́ibro, Postil. Manuscript, Stadtbibliothek (Bautzen), 4o 23.

Jakoubek of Stř́íbro, Postil. Manuscript, Národní knihovna ČR (Prague), X G 11; Knihovna Národního muzea (Prague), XIV E 4.

Jakoubek of Stř́ibro, Postil. Manuscript, Národní knihovna ČR (Prague), VI E 22.

Jakoubek of Stříbro, Postil. Manuscript, Muzeum východních Čech (Hradec Králové), LA 38.

Jan of Příbram, Postil. Manuscript, Národní knihovna ČR (Prague), III H 1.

Prokop of Plzeň, Postil. Manuscript, Národní knihovna ČR (Prague), X G 7.

Prokop of Plzeň, Postil. Manuscript, Národní knihovna ČR (Prague), X H 15.

Jan Rokycana, Postil. Manuscript, Metropolitní kapitula u sv. Víta (Prague), F 59.

Jan Rokycana, Postil. Manuscript, Národní knihovna ČR (Prague), IX A 1.

Martin Lupáč, Postil. Manuscript, Národní knihovna ČR (Prague), I F 50, III D 3.

Václav of Dráchov, Postil. Manuscript, Metropolitní kapitula u sv. Víta (Prague), F 59; Národní knihovna ČR (Prague), IV F 24.

Jakub of Jemnice, Postil. Manuscript, Národní knihovna ČR (Prague), I F 52.

Anonymous (2 $2^{\text {nd }}$ generation of Czech Utraquists), Postil. Manuscript, Metropolitní kapitula u sv. Víta (Prague), F 40.

Anonymous (2 ${ }^{\text {nd }}$ generation of Czech Utraquists), Czech Postil. Manuscript, Strahovská knihovna premonstrátů (Prague), DE V 21.

Anonymous ( $2^{\text {nd }}$ generation of Czech Utraquists), Postil. Manuscript, Národní knihovna ČR (Prague), VI E 24.

Anonymous (2 $2^{\text {nd }}$ generation of Czech Utraquists), Postil. Manuscript, Národní knihovna ČR (Prague), VI E 11.

Anonymous (2 ${ }^{\text {nd }}$ generation of Czech Utraquists), Postil. Manuscript, Metropolitní kapitula u sv. Víta (Prague), F 44/1.

Anonymous (2 ${ }^{\text {nd }}$ generation of Czech Utraquists), Czech Postil. Manuscript, Strahovská knihovna premonstrátů (Prague), DE IV 23.

Anonymous (2 $2^{\text {nd }}$ generation of Czech Utraquists), Postil. Manuscript, Národní knihovna ČR (Prague), III H 11.

Anonymous (2 $2^{\text {nd }}$ generation of Czech Utraquists), Postil. Manuscript, Österreichische Nationalbibliothek (Wien), Cod. 4883.

Anonymous (2nd generation of Czech Utraquists), Postil. Manuscript, Knihovna Národního muzea (Prague), XII F 6.

Anonymous ( $2^{\text {nd }}$ generation of Czech Utraquists), Postil. Manuscript, Knihovna Národního muzea (Prague), XIV E 9. 
Václav, parish priest at St. Gallus in Prague, Postil. Manuscript, Národní knihovna ČR (Prague), XXIII F 113.

Michal Polák, Postil. Manuscript, Národní knihovna ČR (Prague), XI F 3.

Anonymous ( $3^{\text {rd }}$ generation of Czech Utraquists), Postil. Manuscript, Knihovna Národního muzea (Prague), XVI G 4.

Anonymous ( $3^{\text {rd }}$ generation of Czech Utraquists), Postil. Manuscript, Knihovna Národního muzea (Prague), XVI G 14.

\section{Primary Sources (Printed)}

Jan Hus (1907-1908). Sermones de sanctis (Vols. 1-2). Ed. V. Flajšhans. Prague: Jos. R. Vilímek.

Jan Hus (1938-1947). Sermones in Bethlehem 1410-1411 (Vols. 1-6). Ed. V. Flajšhans. Prague:

Královská česká společnost nauk.

Jan Hus (1975). Postilla adumbrata. Ed. B. Ryba. Prague: Academia.

Jan Rokycana (1928-1929). Postilla (Vols. 1-2). Ed. F. Šimek. Prague: Komise pro vydávání pramenů českého hnutí náboženského ve stol. XIV. a XV.

\section{Secondary Sources}

Beran, J. (1931). Mešni liturgie secundum rubicam ecclesiae Pragensis ve st. XV. a XVI. Př́spěvek k vývoji liturgického práva partikulárního v Čechách. Prague: J. Beran.

Ferzoco, G. (1996). Sermon literatures concerning late medieval saints. In B. M. Kienzle et al. (Eds.), Models of Holiness in Medieval Sermons (pp. 103-125). Louvain-La-Neuve: Fédération Internationale des Instituts d'Études Médievales.

Ferzoco, G. (2002). The context of medieval sermon collections on saints. In C. Muessig (Ed.), Preacher, Sermon and Audience in the Middle Ages (pp. 279-292). Leiden: Brill.

Halama, O. (2002). Otázka svatých v české reformaci. Její proměny od doby Karla IV. do doby České konfese. Brno: L. Marek.

Halama, O. (2006). Utrakvistická úcta k českým světcům. In P. Kubín (Ed.), Světci a jejich kult ve středověku (pp. 189-199). České Budějovice: Ústav dějin křestanského umění Katolické teologické fakulty Univerzity Karlovy v Praze v nakl. Tomáš Halama.

Halama, O. (2016). Nad staročeskými svátečními postilami v husitství a utrakvismu. In K. Bracha, \& M. Nodl (Eds.), Česko-polské kazatelské vztahy ve středověku (pp. 119-124). Prague: Filosofia.

Horníčková, K. (2018). Martyrs of "Our" Faith. Identity and the Cult of Saints in Post-Hussite Bohemia. In N. H. Petersen et al. (Eds.), Symbolic Identity and the Cultural Memory of Saints (pp. 59-90). Newcastle upon Tyne: Cambridge Scholars Publishing.

Kadlec, J. (1968). Úcta sv. Prokopa v době husitské, její úpadek v době reformační a obnova v posledních desetiletích před bitvou bělohorskou. In Idem, Svatý Prokop. Český strážce odkazu cyrilometodějského (pp. 101-111). Rome: Křestanská akademie.

Kadlec, J. (1997). Úcta k sv. Vojtěchu v době husitské, její úpadek v době reformační a obnova v posledních desetiletích před bitvou bělohorskou: Svatovojtěšská úcta v českých zemích. In J. V. Polc (Ed.), Svatý Vojtěch. Sbornik k miléniu (pp. 52-55). Prague: Zvon.

Klaniczay, G. (2018). Saints' Cults in Medieval Central Europe: Rivalries and Alliances. In N. H. 
Petersen et al. (Eds.), Symbolic Identity and the Cultural Memory of Saints (pp. 21-41). Newcastle upon Tyne: Cambridge Scholars Publishing.

Kopecký, M. (1965). Cyrilometodějská tradice v starší české literatuře. In J. Macůrek (Ed.), Magna Moravia. Sbornik k 1100. výroči př́chodu byzantské mise na Moravu (pp. 567-586). Prague: Státní pedagogické nakladatelství.

Marek, J. (2005). Husitské postily připisované mistru Václavovi z Dráchova. Miscellanea Odděleni rukopisů a starých tiskü, 18, 4-144.

Marek, J. (2011). Jakoubek ze Střibra a počátky utrakvistického kazatelstvi v českých zemích. Studie o Jakoubkově postile z let 1413-1414. Prague: Národní knihovna ČR.

Marek, J. (2016). Svatováclavská kázání českých utrakvistů. In R. Modráková, \& T. Klimek (Eds.), Cesta $k$ rozmanitosti, aneb, Kavárenský povaleč digitálním historikem středověku. Sbornik př́spěvků $k$ životnimu jubileu PhDr. Zdeňka Uhlǐre (pp. 167-175). Prague: Národní knihovna ČR.

Molnár, A. (1963). Cyrilometodějský motiv v husitství. Náboženská revue, 34, 157-163.

Rejchrtová, N. (1991). Sondy do postilní literatury pokompaktátního (či předbělohorského) utrakvismu. Folia historica Bohemica, 15, 59-71.

Rejchrtová, N. (1997). Svatý Vojtěch v zrcadle české reformace. Teologická reflexe, 3(1), 26-30.

Spunar, P. (1978). Literární činnost utrakvistů doby poděbradské a jagellonské. In A. Molnár (Ed.), Acta reformationem Bohemicam illustrantia 1 (pp. 165-269). Prague: Kalich.

Spunar, P. (1985). Repertorium auctorum Bohemorum provectum idearum post Universitatem Pragensem conditam illustrans I. Wrocław - Warszawa - Kraków - Gdańsk - Łódź: Institutum Ossilinianum.

Spunar, P. (1995). Repertorium auctorum Bohemorum provectum idearum post Universitatem Pragensem conditam illustrans II. Warsaviae \& Pragae: Institutum Ossilinianum.

Šmahel, F. (1971). Kult zemských patronů ortodoxní protiváhou nacionálně zabarvené husitské agitace. In Idem, Idea národa v husitských Čechách (pp. 47-49). České Budějovice: Růže (2nd ed. Prague: Argo 2000, pp. 52-58).

Uhlîr, Z. (1996). Literárni prameny svatováclavského kultu a úcty ve vrcholném a pozdním středověku. Prague: Národní knihovna ČR.

Uhlîr, Z. (2005). Středověké kazatelství v českých zemích. Nástin problematiky. Almanach historyczny, 7, 57-94.

Vidmanová, A. (1997). Hus a svatý Vojtěch. In J. V. Polc (Ed.), Svatý Vojtěch. Sbornik k miléniu (pp. 107-112). Prague: Zvon.

Zlámal, B. (1967). Cyrilometodějská tradice od kompaktát po Komenského. Vlastivědný sbornik moravský, 20, 175-186.

Mgr. Jindřich Marek, Ph.D. / jindrich.marek@ff.cuni.cz

Institute of Information Studies and Librarianship

Charles University, Faculty of Arts

U Kř́žze 8, building B, 15800 Prague 5 - Jinonice, Czech Republic 
Appendix 1: The Number of Sermons on Czech Patron Saints by Jan Hus and Czech Utraquists

Jan Hus

First Generation

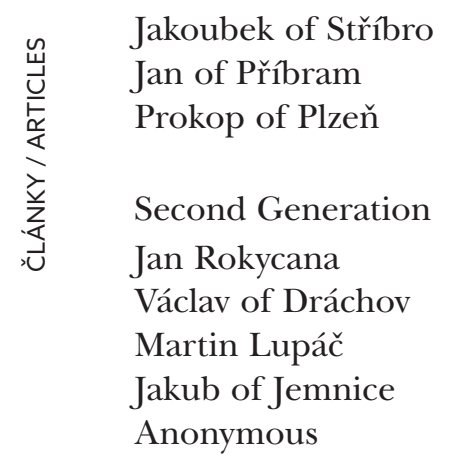

Third Generation

Wenceslaus, parish priest at St Gallus, Prague

Michal Polák

Anonymous

\author{
Sermons Collections \\ 33 \\ 4
}

$\begin{array}{ll}22 & 4 \\ 12 & 1 \\ 3 & 2\end{array}$

$13 \quad 3$

$13 \quad 1$

$5 \quad 1$

$5 \quad 1$

$27 \quad 10$

$\begin{array}{ll}4 & 1 \\ 3 & 1 \\ 16 & 2\end{array}$


Appendix 2: List of Sermons by Jan Hus on Czech Patron Saints

\section{VITUS}

v1

Puncta

Manuscript used: NK, IV F 25 71v-72v

Lk 22:36b, Mt 10:34

v2

Sermones de sanctis

Ed. Hus (1907-1908), No. XX, pp. 69-74

Mt 10:34

v3

Sermones de sanctis

Ed. Hus (1907-1908), No. LXI, pp. 321-325

Heb 11:33

v4

Sermones in Bethlehem

Ed. Hus (1938-1947), vol. IV, No. CXC, pp. 203-207

Mt 10:34

v5

Sermones in Bethlehem

Ed. Hus (1938-1947), vol. IV, No. CXCI, pp. 207-211

Heb 11:33

\section{PROCOPIUS}

p1

Puncta

Manuscript used: NK, IV F 25, ff. $77 \mathrm{v}-79 \mathrm{r}$ Sir 45:1

p2

Sermones de sanctis

Ed. Hus (1907-1908), No. XXV, pp. 96-97

(Procopius or any confessor of the faith) Mt 24:46 (Lk 12:43) p3

Sermones de sanctis

Ed. Hus (1907-1908), No. XXVI, pp. 98-102

Lk 12:35

$\mathrm{p} 4$

Sermones in Bethlehem

Ed. Hus (1938-1947), vol. IV, No. CCI, pp. 250-255

Lk 12:35

p5

Sermones in Bethlehem

Ed. Hus (1938-1947), vol. IV, No. CCII, pp. $255-257$

Mt 24:42

p6

Postilla adumbrata

Ed. Hus (1975), pp. 310-313

Mt 24:42

\section{WENCESLAUS}

w1

Puncta

Manuscript used: NK, IV F 25, ff. 111r-112v

Gen 49:8

w2

Sermones de sanctis

Ed. Hus (1907-1908), No. XLI, pp. 175-181 Uhlirir (1996), No. 121, p. 233 Mt 16:24

w3

Sermones de sanctis

Ed. Hus (1907-1908), No. XLII, pp. 181-184, cf. Uhlîr (1996), No. 101, pp. 214-215)

Mt 16:24 


\section{w4}

Sermones in Bethlehem

Ed. Hus (1938-1947), vol. V, No. CCXLVIII, pp. 78-80, cf. Uhlî́r (1996), No. 135, pp. 244-245)

Mt 24:4

\section{w5}

Sermones in Bethlehem

Ed. Hus (1938-1947), vol. V, No. CCXLIX, pp. 80-82, cf. Uhlîr (1996), No. 111, pp. 224-225)

Mt 16:24

w6

Sermones in Bethlehem

Ed. Hus (1938-1947), vol. V, No. CCL, pp. 82-85, cf. Uhlír (1996), No. 4, pp. 120-121)

Sir 31:8

\section{w7}

Sermones in Bethlehem

Ed. Hus (1938-1947), vol. V, No. CCLII, pp. 88-94, cf. Uhlír (1996), No. 110, pp. 223-224)

Mt 16:24

w8

Sermones in Bethlehem, Postilla adumbrata

Ed. Hus (1938-1947), vol. V, No. II, pp. 136-140; cf. Uhlír (1996), No. 106, pp. 219-220); Ed. Hus (1975), pp. 432-437;

cf. Uhlîr (1996): not enlisted

Mt 16:24

\section{LUDMILA}

11

Puncta

Manuscript used: NK, IV F 25, ff. 104r$105 \mathrm{v}$

Esth 5:1

\section{2}

Sermones de sanctis

Ed. Hus (1907-1908), No. XXXVIII, pp. 163-164 (165-166)

Lk 21:1

13

Sermones de sanctis

Ed. Hus (1907-1908), No. LXXV, pp. 376-379

1 Thess 5:3b

14

Sermones in Bethlehem

Ed. Hus (1938-1947), vol. V, No. CCXLI, pp. $57-59$

1 Thess 5:3b

15

Sermones in Bethlehem

Ed. Hus (1938-1947), vol. V, No. CCXLII, pp. 59-62 (Ludmila and Eufemia)

Eccl 51:3.

16

Postilla adumbrata

Ed. Hus (1975), pp. 414-415

no pericope

\section{SIGISMUND}

\section{s1}

Sermones in Bethlehem

Ed. Hus (1938-1947), vol. IV, No. CLXVI, pp. 92-99

Jn 15:1

\section{ADALBERT}

a1

Sermones de sanctis

Ed. Hus (1907-1908), No. LIV, pp. 289-296

Jn 15:1 
a2

Sermones de sanctis

Ed. Hus (1907-1908), No. LVIII, pp.

307-312

Sap 10:10

a3

Sermones in Bethlehem

Ed. Hus (1938-1947), vol. IV, No. CLIX, pp. 62-66 (George and Adalbert)

1 Pet 2:9

a4

Sermones in Bethlehem

Ed. Hus (1938-1947), vol. IV, No. CLX, pp. 67-71 (George and Adalbert)

Heb 13:17 a5

Postilla adumbrata

Ed. Hus (1975), pp. 558-559 (Adalbert and George)

Jn 15:1

\section{THE FIVE BROTHERS}

fb 1

Sermones in Bethlehem

Ed. Hus (1938-1947), vol. I, No. VIII, pp. 49-58

Lk 12:1b

fb2

Postilla adumbrata

Ed. Hus (1975), pp. 500-505

Lk 12:1b 
Appendix 3: List of Medieval Utraquist Sermons on Czech Patron Saints

\section{VITUS}

\section{V1}

Jakoubek of Stř́ibro

Bautzen, Stadtbibliothek, $4^{\circ}$ 23, ff. 199r$200 \mathrm{v}$

Mt 10:34

V2

Jakoubek of Stříbro

NK, X G 11, ff. $67 \mathrm{r}-68 \mathrm{v}$

Mt 10:34

\section{V3}

Jakoubek of Stříbro

NK, XIV E 4, ff. 172r-174r

Mt 10:34

\section{V4 (same as V8)}

Jakoubek of Stříbro

Hradec Králové, Muzeum východních

Čech, LA 38, ff. 159v-161r

Mt 10:34

\section{V5}

Jan of Příbram

NK, III H 1, ff. 207r-208v

Mt 10:34

\section{V6}

Jan of Př́ibram

NK, III H 1, ff. 263v-265v

Mt 10:34

V7

Prokop of Plzeň

NK, X H 15, ff. 158v-161r

Mt 10:37

V8 (same as V4)

Jan Rokycana
Kapit, F 59, ff. 338r-339v

Mt 10:34

V9

Jan Rokycana

Kapit, F 59, ff. 339v-340v

Mt 10:34

V10

Jan Rokycana

Kapit, F 59, ff. 340v-342v

Mt 10:34

\section{V11}

Jan Rokycana

Ed. Rokycana (1928-1929), vol. II, pp. 780-794 (Czech language)

Mt 10:34 (and Heb 11,33 quoted in one manuscript)

\section{V12}

Martin Lupáč

NK, I F 50, ff. 6r-6v; NK, III D 3, ff. 293v

Mt 10:34

V13

Václav of Dráchov

Kapit, F 59, ff. 273v-277r

Mt 10:34

\section{V14}

Václav of Dráchov

Kapit, F 59, ff. 277r-280v

Heb 11:33

V15 (same as V16)

Jakub of Jemnice

NK, I F 52, ff. 59v-62v (old foliation: $73 \mathrm{v}-$ $76 \mathrm{v})$

Mt 10:34 
V16 (same as V15)

Anonymous (Second Generation)

Kapit, F 40, fol. 71v; Wien, Österreichische

Nationalbibliothek, Cod. 4883, ff. 97v-99v

Mt 10:34

\section{V17}

Anonymous (Second Generation)

Kapit, F 44/1, fol. 76rv (Vitus and Modestus)

Lk 22:36b

V18 (vernacular version of V15 and V16)

Anonymous (Second Generation)

Strahov, DE IV 23 ff. 99r-108v (Czech language)

Mt 10:34

V19

Anonymous (Second Generation)

KNM, XII F 6, ff. 117r-121r

Mt 10:34

V20

Anonymous (Second Generation)

KNM, XII F 6, fol. 238v

Mt 10:34

V21

Anonymous (Second Generation)

KNM, XIV E 9, ff. 88r-91v

Mt 10:34

V22

Anonymous (Second Generation)

KNM, XIV E 9, ff. 296v-297v

Mt 10:34

V23

Anonymous (Second Generation)

KNM, XIV E 9, ff. 436r-438r

Mt 10:34

\section{V24}

Michal Polák

NK, XI F 3, ff. 233v-240r

Mt 10:34

V25

Anonymous (Third Generation)

KNM, XVI G 4, ff. 38r-44r

no pericope + Mt 10:34

V26

Anonymous (Third Generation)

KNM, XVI G 14, ff. b58r-b59r

Heb 11:33

V27

Anonymous (Third Generation)

KNM, XVI G 14, ff. b59v-c2b

Mt 10:34

\section{PROCOPIUS}

P1

Jakoubek of Stř́ibro

Bautzen, Stadtbibliothek, 4o 23, ff. 218v$219 \mathrm{r}$

Lk 12:35

P2

Jakoubek of Stř́ibro

Bautzen, Stadtbibliothek, $4^{\circ}$ 23, ff. 219r220v

Lk 12:35

P3

Jakoubek of Stříbro

NK, X G 11, ff. 89v-92v

Lk 12:35

P4

Jakoubek of Stříbro

NK, X G 11, ff. 92v-93r

Lk 12:35 


\section{P5}

Jakoubek of Stříbro

NK, VI E 22, ff. 1r-6r

Lk 12:35

\section{P6}

Jakoubek of Stříbro

Hradec Králové, Muzeum východních

Čech, LA 38, ff. 176v-179r

Lk 19:12

\section{P7}

Jan of Př́bram

NK, III H 1, ff. 22r-25r (Feast of Gallus,

Giles, Procopius and All Confessors of the

Faith; Preached on the Feast of Gallus)

Ps 54:8

\section{P8}

Jan of Př́ibram

NK, III H 1, ff. 238r-239v

Lk 12:35

\section{P9}

Prokop of Plzeň

NK, X G 7, ff. 220v-222v

Sir 45:1

\section{P10}

Jan Rokycana

Kapit, F 59, ff. 347r-349v

Lk 8:16

\section{P11}

Jan Rokycana

Kapit, F 59, ff. 349v-351v

Mt 25:14

\section{P12}

Jan Rokycana

NK, IX A 1, fol. 222r

Lk 12:35

\section{P13}

Martin Lupáč

NK, I F 50, fol. 15r

Mt 12:46

\section{P14}

Martin Lupáč

NK, I F 50, ff. 93v-94v

Jas 5:16b

\section{P15}

Martin Lupáč

NK, I F 50, ff. 301r; NK, III D 3, fol. 298rv

Lk 12:35

\section{P16}

Václav of Dráchov

Kapit, F 59, ff. 20r-23r

Lk 12:35

\section{P17}

Jakub of Jemnice

NK, I F 52, ff. $78 \mathrm{v}-82 \mathrm{v}$ (old foliation: $92 \mathrm{v}-$ 96v)

Lk 12:35

P18 (vernacular edited and extended version of P17)

Anonymous (second Generation)

Strahov, DE IV 23, ff. 160r-171r (Czech

Language)

Mt 24:42 + Lk 12:35

\section{P19}

Anonymous (Second Generation)

KNM, XII F 6, ff. 134v-136r („De confessore non pontifice“, added: „Procopii“)

Lk 8:16

\section{P20}

Anonymous (Second Generation)

KNM, XIV E 9, ff. 107r-111v

Lk 12:35 
P21

Anonymous (Second Generation)

KNM, XIV E 9, ff. 442v-444v

Lk 12:35

\section{P22}

Wenceslaus, Parish Priest at St. Gallus, Prague

NK, XXIII F 113, ff. 44r-45v

Lk 12:35

\section{P23}

Anonymous (Third Generation)

KNM, XVI G 4, ff. 64r-68v

Lk 12:35

\section{P24}

Anonymous (Third Generation)

KNM, XVI G 14, ff. c31r-c32v

Sir 45:1

\section{WENCESLAUS}

W1

Jakoubek of Stříbro

Bautzen, Stadtbibliothek, $4^{\circ}$ 23, 258r260r; NK, VI E 22, fol. 140v (and on appended leaf)

Mt 16:24

\section{W2}

Jakoubek of Stříbro

NK, X G 11, ff. 153v-155v

Mt 16:24

\section{W3}

Jakoubek of Stříbro

NK, VI E 22, ff. 140v-141v

Mt 16:24

\section{W4}

Jakoubek of Stříbro

Hradec Králové, Muzeum východních Čech, LA 38, ff. 257r-260v
Mt 16:24

\section{W5}

Jan of Příbram

NK, III H 1, ff. 52r-53v

Mt 16:24

W6

Jan of Příbram

NK, III H 1, ff. 53v-56v

Mt 16:24

W7

Jan Rokycana

NK, IX A 1, ff. 243v-244r

Mt 16:24

\section{W8}

Martin Lupáč

NK, I F 50, fol. 102rv; NK, III D 3, ff. 309v-310r, cf. Uhlír (1996), No. 100, pp. 213-214

Mt 16:24

W9

Václav of Dráchov

Kapit, F 59, ff. 139r-139v

Mt 16:24

\section{W10}

Václav of Dráchov

Kapit, F 59, ff. 139v-141v

Mt 16:24

\section{W11}

Václav of Dráchov

Kapit, F 59, fol. 143rv

Mt 16:24

\section{W12}

Jakub of Jemnice

NK, I F 52, ff. 129r-133r (old foliation: ff. 143r-147r), cf. Uhlír (1996), No. 115, pp. 
228-229

Mt 16:24

\section{W13}

Anonymous (Second Generation)

Kapit, F 44/1, fol. 77rv

Sir 31:8

W14 (vernacular, edited and extended version of $\mathrm{W} 12$ )

Anonymous (Second Generation)

Strahov, DE IV 23, ff. 312r-325r (Czech language)

Mt 16:24

\section{W15 (edited version of W12)}

Anonymous (Second Generation)

NK, III H 11, ff. 255v-260v

Mt 16:24

\section{W16}

Anonymous (Second Generation)

KNM, XII F 6, ff. 183v-187r

Mt 16:24

\section{W17}

Anonymous (Second Generation)

KNM, XIV E 9, ff. 154v-157v, cf. Uhlír (1996), No. 105, pp. 218-219, here listed: Nelahozeves, Roudnická lobkowiczká knihovna, VI Fe 19, pp. 467-476

Mt 16:24

\section{W18}

Anonymous (Second Generation)

KNM, XIV E 9, ff. $417 \mathrm{v}-419 \mathrm{v}$

Mt 16:24

\section{W19}

Wenceslaus, Parish Priest at St. Gallus, Prague

NK, XXIII F 113, ff. 150v-152v

Mt 16:24

\section{W20}

Wenceslaus, Parish Priest at St. Gallus, Prague

NK, XXIII F 113, ff. 152v-154r

Sir 31:8

\section{W21}

Anonymous (Third Generation)

KNM, XVI G 14, ff. b15v-b17v (Feast of the Translation of St Wenceslaus)

Sir 31:10

\section{W22}

Anonymous (Third Generation)

KNM, XVI G 14, ff. e2v-e4v

Sir 31:10b

\section{LUDMILA}

\section{L1}

Jakoubek of Střríbro

Bautzen, Stadtbibliothek, $4^{\circ}$ 23, ff. 250rv

Mt 13:44

\section{L2}

Jan of Příbram

NK, III H 1, ff. 35v-39v

Mt 13:44

\section{L3}

Jan of Příbram

NK, III H 1, ff. 40r-46r

Prov 31:10

\section{L4 (same as L8)}

Jan of Příbram

NK, III H 1, ff. 98r-99v (Feast of the Translation of St Ludmila)

Esth 5:1

\section{L5}

Prokop of Plzeň

NK, X G 7, ff. 267r-270r

Mt 13:44 
L6

Jan Rokycana

NK, IX A 1, fol. 242r

Mk 12:41

\section{L7}

Václav of Dráchov

Kapit, F 59, ff. 123r-124r (unfinished version of the same text on fol. 122r)

1 Thess 5:3b

\section{L8 (same as L4)}

Václav of Dráchov

Kapit, F 59, ff. 124r-127v

Prov 31:10

\section{L9}

Václav of Dráchov

Kapit, F 59, ff. 128r-133v

Mt 13:44

\section{L10}

Anonymous (Second Generation)

NK, VI E 24, ff. 78r-79v

Esth 5:1

\section{L11}

Anonymous (Second Generation)

NK, VI E 24, ff. 80r-81r

1 Thess 5:3b

\section{L12}

Anonymous (Second Generation)

KNM, XIV E 9, ff. 496v-499r

Mt 13:44

L13

Wenceslaus, Parish Priest at St. Gallus, Prague

NK, XXIII F 113, ff. 142v-144v

1 Thess 5:3b

\section{L14}

Anonymous (Third Generation)

KNM, XVI G 4, ff. 68v-74r (the name of Ludmila added on fol. $69 \mathrm{r}$, the sermon is on Margaret)

Mt 13:44

\section{L15}

Anonymous (Third Generation)

KNM, XVI G 4, ff. 135v-142r

Mt 13:44

\section{L16}

Anonymous (Third Generation)

KNM, XVI G 14, ff. d34v-d36r

Sir 51:14

\section{SIGISMUND}

S1

Jakoubek of Stříbro

Bautzen, Stadtbibliothek, 4 23, ff. 172r$173 v$

Ezek 8:5 (replacement pericope due to use of the original on the feast of Adalbert)

\section{S2}

Jakoubek of Stř́ibro

NK, X G 11, ff. 37v-39r

Jn 15:1

S3

Jakoubek of Stříbro

KNM, XIV E 4, ff. 131v-135v

Jn 3:1 (replacement pericope due to use of the original on the feast of Adalbert)

\section{S4}

Jan of Příbram

NK, III H 1, ff. 202v-205r

Lk 18:18 


\section{S5}

Jan Rokycana

Kapit, F 59, ff. 336r-338r

Wis 5:1 (replacement pericope due to use of the original on the feast of Adalbert)

\section{S6}

Jan Rokycana

NK, IX A 1, fol. 181v

Jn 15:1

\section{S7}

Jan Rokycana

NK, IX A 1, fol. ff. 183v

Jn 15:17

\section{S8}

Václav of Dráchov

Kapit, F 59, ff. 264v-266r

Heb 11:33

\section{S9}

Václav of Dráchov

Kapit, F 59, ff. 266r-267v

Wis $5: 1$

S10

Anonymous (Second Generation)

KNM, XII F 6, ff. 108r-111v

Jn 15:5

\section{S11}

Anonymous (Second Generation)

KNM, XIV E 9, ff. 83r-84v

Jn 15:5

\section{S12}

Anonymous (Second Generation)

KNM, XIV E 9, ff. 389v-390v

Jn 15:5

S13

Michal Polák
NK, XI F 3, ff. 225r-229v

Jn 14:6 (replacement pericope due to use of the original on the feast of George)

\section{S14}

Anonymous (Third Generation)

KNM, XVI G 4, ff. 19v-22r (Philip or Sigismund)

Wis $5: 1$

\section{S15}

Anonymous (Third Generation)

KNM, XVI G 14, ff. b40r-b42r

Heb 11:33

\section{ADALBERT}

\section{A1}

Jakoubek of Stř́ibro

Bautzen, Stadtbibliothek, $4^{\circ}$ 23, ff. 163v$165 \mathrm{r}$

Jn 15:1

A2

Jan of Př́bram

NK, III H 1, ff. 191v-193r

Jn 15:1

\section{A3}

Jan Rokycana

NK, IX A 1, fol. 181v

Jn 15:1

A4

Václav of Dráchov

Kapit, F 59, ff. 255r-258r (Adalbert and George)

Jn 15:1

A5

Václav of Dráchov

NK, IV F 24, ff. 234v-243r (Adalbert and George)

Jn 15:1 


\section{A6}

Anonymous (Second Generation)

NK, VI E 11, ff. 152v-153r (Adalbert and George)

Jn 15:1

\section{A7}

Michal Polák

NK, XI F 3, ff. 202v-209r (Adalbert and George)

Jn 15:5

\section{A8}

Anonymous (Third Generation)

KNM, XVI G 14, ff. b36v-b37v

Wis $10: 10$

\section{FIVE BROTHERS}

\section{FB1}

Jakoubek of Stříbro

Bautzen, Stadtbibliothek, $4^{\circ}$ 23, ff. 288r$289 \mathrm{v}$

Lk 12:1b

\section{FB2}

Jakoubek of Stříbro

NK, X G 11, ff. 166v-168v

Lk 12:1b

\section{FB3}

Jakoubek of Stříbro

Hradec Králové, Muzeum východních

Čech, LA 38, ff. 292r-295r

Lk 12:1b

\section{FB4}

Jan of Příbram

NK, III H 1, ff. 106v-108v

Lk 12:1b

\section{FB5}

Jakub of Jemnice

NK, I F 52, ff. 161r-162r (old foliation: 175r-176v)

no pericope

\section{FB6}

Jakub of Jemnice

NK, I F 52, ff. 162r-165v (old foliation: $176 \mathrm{v}-179 \mathrm{v})$

Lk 12:1

\section{FB7}

Anonymous (Second Generation) Kapit, F 40, ff. 127r-128r; NK, VI E 24, ff. $38 \mathrm{v}-40 \mathrm{v}$

Lk 12:1b

\section{FB8}

Anonymous (Second Generation)

Strahov, DE V 21, ff. 207v-213r (Czech language)

Ps 132:1

\section{FB9}

Anonymous (Third Generation)

KNM, XVI G 14, ff. e36v-e38v

Sir 44:14

\section{GYRIL AND METHODIUS \\ CM1}

Anonymous (Third Generation)

KNM, XVI G 14, ff. b17v-b19r

Prov 10:28

\section{CM2}

Anonymous (Third Generation) KNM, XVI G 14, ff. b19r-b20bisv Heb 7:2 
